
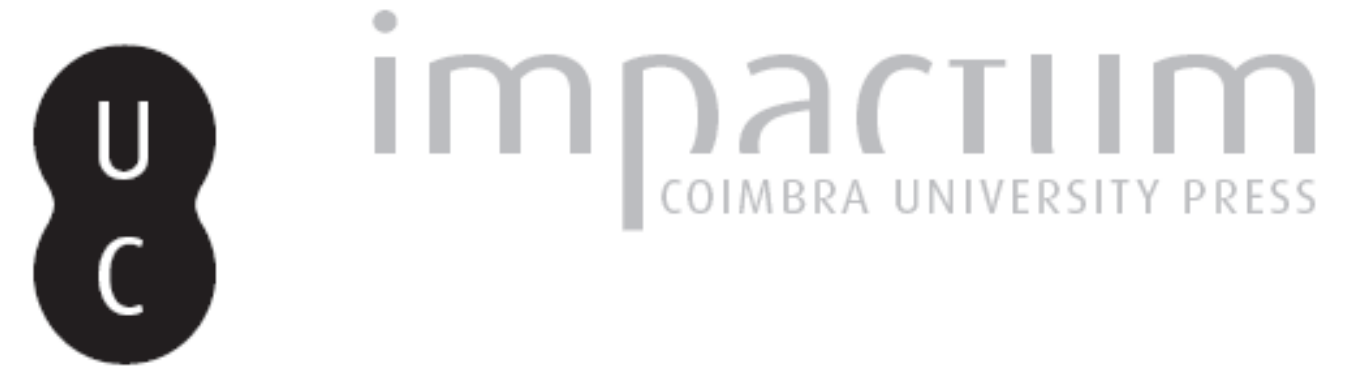

\title{
Meanwhile use as an act of resistance
}

\section{Autor(es): Leyssen, Dieter}

Publicado por: Editorial do Departamento de Arquitetura

URL persistente:

URI:http://hdl.handle.net/10316.2/45185

DOI:

DOl:https://doi.org/10.14195/1647-8681_9_7

Accessed : $\quad 26-A p r-2023$ 02:45:10

A navegação consulta e descarregamento dos títulos inseridos nas Bibliotecas Digitais UC Digitalis, UC Pombalina e UC Impactum, pressupõem a aceitação plena e sem reservas dos Termos e Condições de Uso destas Bibliotecas Digitais, disponíveis em https://digitalis.uc.pt/pt-pt/termos.

Conforme exposto nos referidos Termos e Condições de Uso, o descarregamento de títulos de acesso restrito requer uma licença válida de autorização devendo o utilizador aceder ao(s) documento(s) a partir de um endereço de IP da instituição detentora da supramencionada licença.

Ao utilizador é apenas permitido o descarregamento para uso pessoal, pelo que o emprego do(s) título(s) descarregado(s) para outro fim, designadamente comercial, carece de autorização do respetivo autor ou editor da obra.

Na medida em que todas as obras da UC Digitalis se encontram protegidas pelo Código do Direito de Autor e Direitos Conexos e demais legislação aplicável, toda a cópia, parcial ou total, deste documento, nos casos em que é legalmente admitida, deverá conter ou fazer-se acompanhar por este aviso.

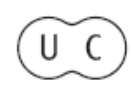



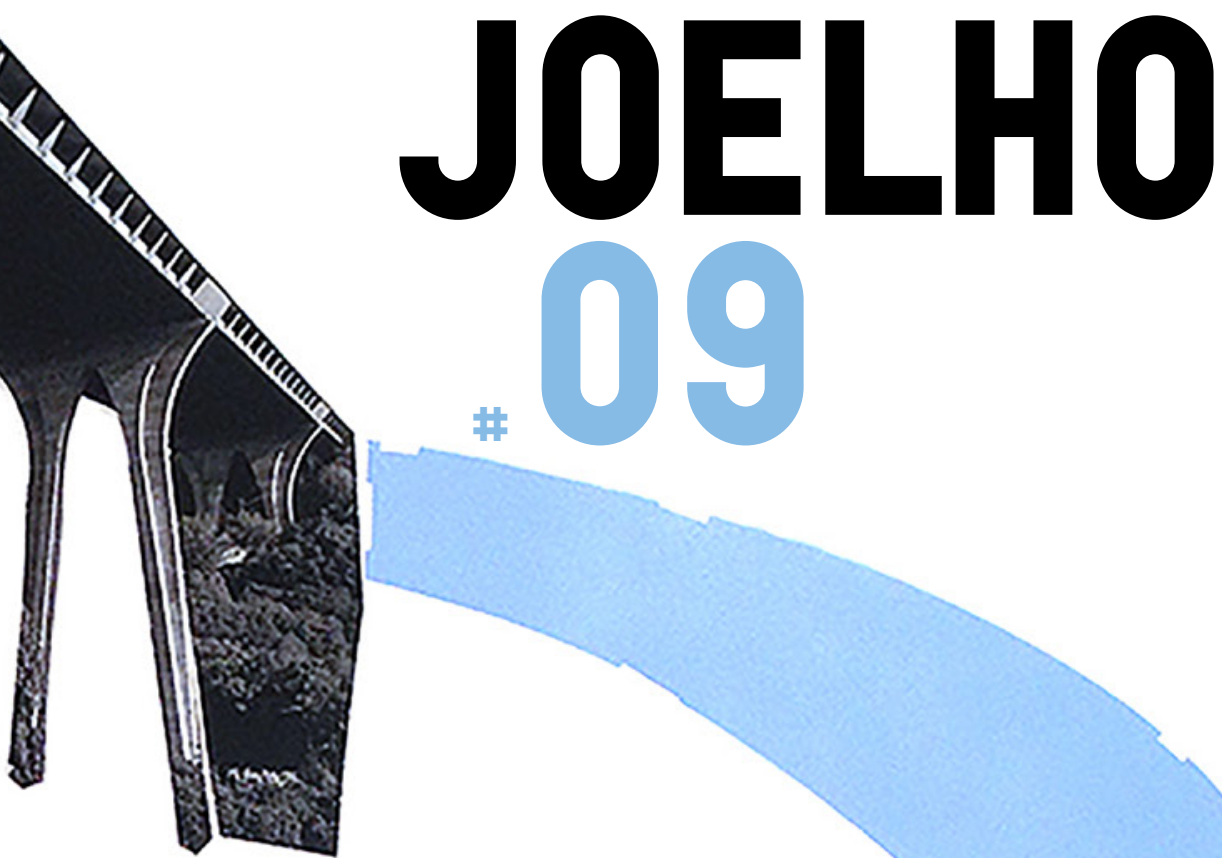

\section{REUSE OF MODERNIST BUILDINGS: PEDAGOGY AND PROFESSION}

Guest Editors:

Michel Melenhorst

Paulo Providência

Gonçalo Canto Moniz

ZUS: Elma van Boxel

and Kristian Koreman

Atelier do Corvo

Tilemachos Andrianopoulos

Albena Yaneva

Carlos Fortuna

Christian Gänshirt

Dieter Leyssen

Carolina Coelho

Anna Giovannelli

António Carvalho

Marta Peixoto

Els De Vos

and Eva Storgaard

Exhibition

$2^{\text {nd }}$ RMB Workshop, Coimbra

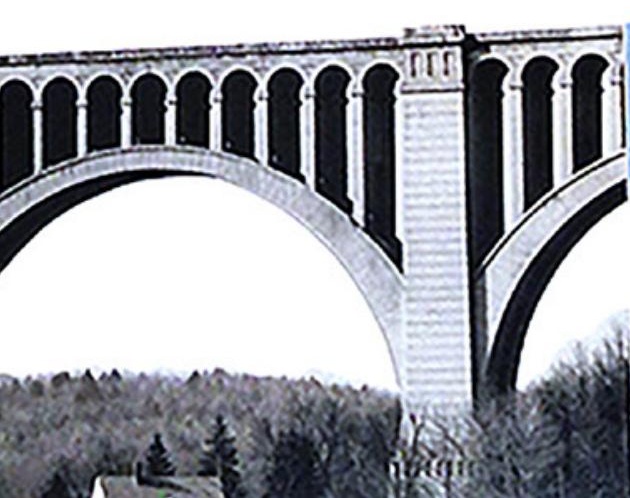




\section{Dieter Leyssen \\ Meanwhile Use as an \\ Act of Resistance}

LSE - London School of

Economics and Political Science

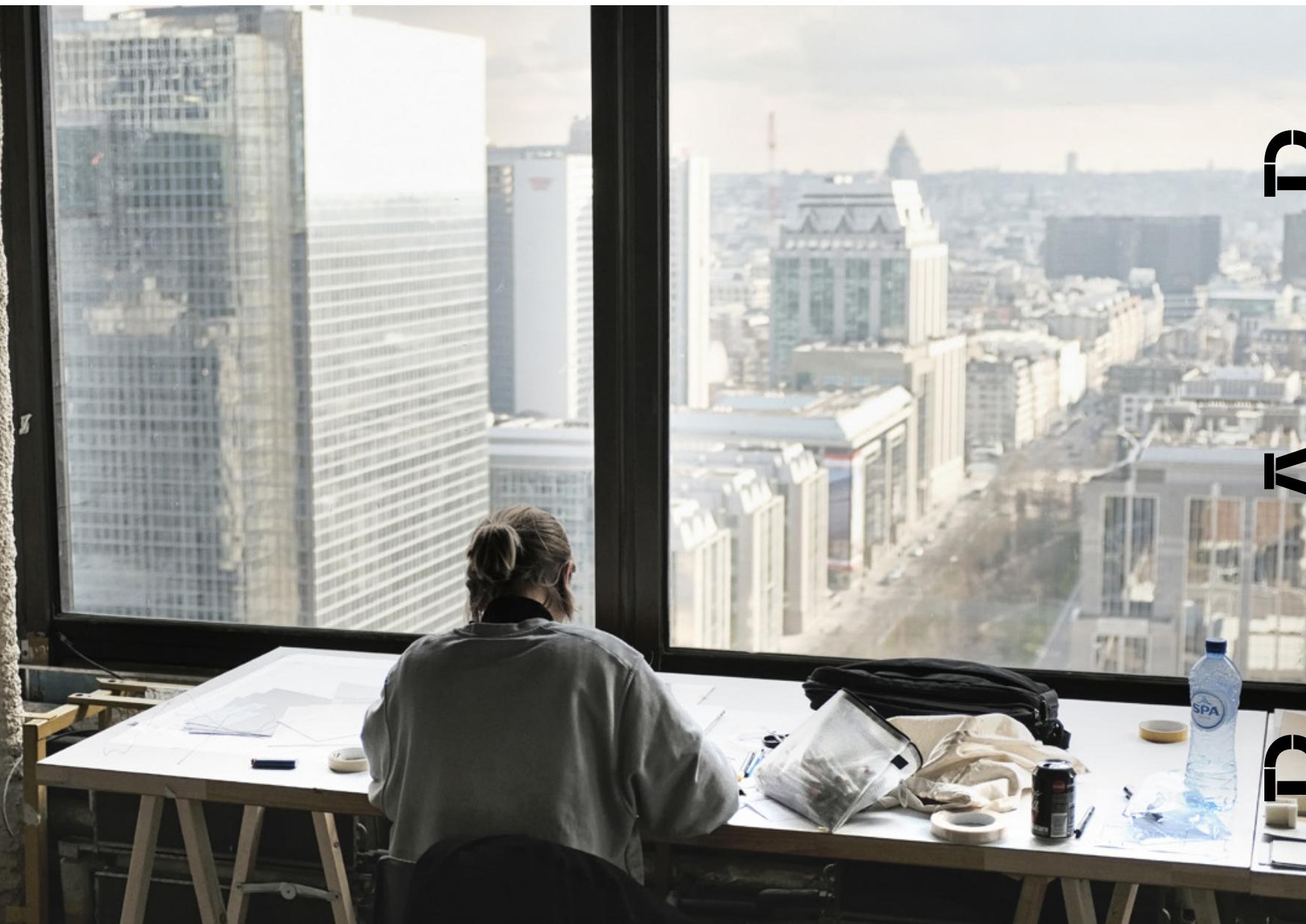




\section{Introduction}

In 2017, an open call was launched for temporary users of vacant office spaces in the Brussels North District. This business district characterised by office towers and large boulevards had recently fallen victim to increased vacancy and disinvestment. Following this call, one of the most emblematic vacant buildings of the district, the World Trade Centre is gradually opened up to over fifty small organisations, an architecture school's studio and various colloquial events. The modernist architecture of this tower stayed largely the same as designed 50 years ago. Only today, its marble-cladded hallway and globe-shaped entrance desk no longer welcome bankers and civil servants but students, artists, architects, cooks, and many others. Its elevator's polished steel walls are stuck with flyers for temporal exhibitions, healthy meals, 'body practice' or critical pamphlets with titles such as 'students as lure-hipsters!?' Whilst the contrasting aesthetics and creative atmosphere of the place are attractive, one wonders what this condition represents. Is this type of meanwhile use a symptom of post-crisis urbanism, embracing the aesthetics of scarcity and flexible live-work tendencies? Is it an interim use to test out programs that can later on be integrated in a new development? Or does it merely reflect a strategy to "keep vacant sites warm while development capital is cool' (Tonkiss 2013, pp. 323).

Meanwhile use of buildings is not new. Buildings and entire districts have always housed temporary uses, different from those they were designed for. Today, we see increased interest in meanwhile use in the context of urban redevelopment projects. Examples can be found in cities all over the world: car parks are temporarily turned into artist studios, in-between spaces into vegetable gardens, vacant offices into galleries, etc. Within this growing collection of cases, important differences surface in terms of ideology, politics of space, activism and power relations. In each particular case, the question of who ultimately benefits from the meanwhile use can be raised.

Many authors have highlighted the catalyst role of practices of squatting and temporary use in processes of gentrification and of displacement of local communities (Metaal 2007; Suleiman 2011; Smith 1996; Zukin 2010). Margret Mayer (2013, pp. 11) highlights how practices of meanwhile use are being used as 'branding assets' by public authorities and the real estate market. This essay seeks to contribute to the discussion by looking at critical conditions that define cases of meanwhile use. It is an attempt to understand its more visceral registers, its empowering potential and its traps. Fran Tonkiss (2013, pp. 322) explains how meanwhile use is often simultaneously 'good and bad'. Good, because it materialises, even in ephemeral and temporal ways, principles that are critical to the 'business-as-usual'. Bad, because it enrols, consciously or not, in a culture of 'the low - or no-cost'. (Tonkiss 2013) Doing so, it remains a weak player in the high-risk high-reward game of urban development. Can this practice be an act of resistance affecting the further course of urban redevelopment projects? More
Frontispiece Student of KULeuven Faculty of Architecture, Sint-Lucas Brussels working on the $24^{\text {th }}$ floor, while overlooking the central axis of the Brussels North District (copyright Alexis Gicart) 
specifically, can it influence and inform the choices of citizens, policy makers, architects and developers in that project? I argue it can, when certain conditions are fulfilled.

I make this argument using literature from the tradition of critical urbanism, post-colonial theory, and actor-network theory. In the first part, I introduce the two main concepts that I use to sustain my argument: meanwhile use and resistance. Subsequently, I argue that meanwhile use can affect the future of urban sites during the 'unstable' moment of redevelopment. In the second part, I introduce a case study, by ways of a tour along three different practices part of the meanwhile use in the Brussels North District. In the third part, I crystallise from the case and the literature five conditions for meanwhile use to be an act of resistance. They tap into questions within meanwhile use, such as its method and approach, as well as questions of its context, such as its economical and temporal condition. I conclude by outlining how meanwhile use as an act of resistance can make a positive contribution to urban transformation in the context the neo-liberal city.

\section{Meanwhile use as act of resistance, an actor-network approach}

Meanwhile use is defined as the 'interim' use of a site while it is undergoing a transformation. Permanent use is the use of a site while it is, more or less, stable. Meanwhile use is often characterised by temporal spatial interventions and events, closely related to the concept of informal urbanism in post-colonial theory (Mehotra 2011). It is associated with ephemeral structures, cheap materials and contrasting aesthetics. Permanent use on the other hand is associated with formality and thus coherent structures that require large investments. While most literature on informal use relies on records from cities in the so-called Global South, Boudreau (2017) argues that forces of 'informalization' are also at stake in cities of the so-called Global North. She argues that an 'informalization of the state' is taking place, highlighting urban forms of organisation, use and distribution of power that 'exceeds formal institutions' (Boudreau 2017, pp. 171).

Another binary stance that is instructive in the definition of meanwhile use is Lefebvre's concept of representation of space and representational space. Let us take an example from the Brussels' case: a business district used 'permanently' by business people might be associated with the representation of space, i.e. it is planned, ordered and controlled, while a temporal short-term use by students and artists is associated with representational space, i.e. appropriated, lived and as space-in-use (Lefebvre 1991, cited in Mittchel 1995, pp. 115).

Though they are helpful in defining some characteristics, both theories do not explain the reciprocal relation between meanwhile use and the permanent use. I believe this relation lies in the potential for resistance.

Resistance is defined as the force that critically interrogates a certain process, intending to have an impact on its outcome. In urban 
redevelopment projects, resistance takes various shapes, depending on the actors at stake. I focus on types of resistance 'from within.' Tonkiss (2013, pp. 317) points to the concept of 'crack capitalism', defined by John Holloway (2010) and further developed by Stuart Hodkinson (2012). They highlight a resistance to the increasing privatisation of urban land by practices that force 'open the cracks in these contexts' through 'identifying the weaknesses, the joins, the blind spots and inconsistencies in a given strategy or settlement, and working both against and within them' (Tonkiss 2013).

Actor-Network theory can help us understand how meanwhile use can exert such resistance. The theory recognises that objects, amongst which buildings and build environments, can have agency and are 'things' inside of networks, 'always in-the-making' (Latour et al. 2008). In this tradition, cities are studied not as 'organised and functional' but as 'complex entities of stakes, ideas, actors and practices' (Stengers 2000, as cited in Doucet 2015, pp. 19). In stable periods, these complex networks of actors and stakes are 'black-boxed' in the build form of the city (Gieryn 2002). During the redevelopment of an urban site, they can be more easily accessed. The disentangled stakes can subsequently be rewired to newly introduced agendas, leading in alternative results. Because meanwhile use takes place in this unstable period, it can have agency as a resisting force by opposing decisions and presenting alternatives. It can, for instance, develop and prove the viability of its program, actors or economic model so that, in the end, the temporal use is integrated in the final building program.

\section{The Brussels North District}

The Brussels North District is a 53 ha office district in the centre of Brussels. Its utopian modernist masterplan, infamously called 'the Manhattan-plan', imagined an international business district that would attract large multinationals to the city of Brussels. Several multi-story office towers would come to articulate the crossroad of two highways - connecting London to Istanbul and Stockholm to Lisbon - in the centre of the district. The construction of the district caused the eviction of 3000 families of two working class neighbourhoods (Martens 2009). Ultimately, the new highways never got build and the arrival of international corporations lingered on. For years, the area became a large wasteland in the middle of the city. Finally, the government salvaged the developers by taking long-term leases on the majority of offices in the district. Today, these leases are gradually ending, leaving the district with a prospect vacancy rate of $20 \%$ (Bogdan et al. 2013; Binst 2016).

The North District ranks as one of Brussels most 'traumatic' developments that shaped the city since the late $19^{\text {th }}$ century (Doucet 2015, pp. 39). At daytime, commuters rush from their office to the train station. At night, it is characterised by petty criminality and prostitution. Joris Sleebus, a former city guide, saw the deconstruction 
happening: '12,000 evicted, for which alternative housing facilities got delivered only 7 years later? (...) Until now I still feel the anger and outrage' (Interview 2017).

This negative stigma stimulates a strong asocial attitude of its users towards the district. One of the large banks located at the edge of the district even installed a shuttle service so that its employees could skip the 10-minute walk from the station to the office. Because of its central location, its large boulevards and over-sized public spaces, it became a prime location for protests and manifestations of all kinds. Finally, during the 2015 refugee crisis, the largest park in the district became a large encampment of people, waiting to access the immigration services.

Lately, the negative stigma is being countered by a series of interrelated events. First, and most importantly, the property owners were confronted by the increasing vacancy rate and started looking for alliances to safeguard the future of the district. Secondly, the increasingly vacant North District hit the radar of various citizen groups, mainly from an artistic and architectural milieu, claiming the spaces for temporal events and workshops. Thirdly, catalysed by the former two, the Brussels' Master Architect, a position installed in 2009 that aims to steer the architectural quality in the region, showed increased interest in the future of the district. Amid their different agendas, those three actor groups agreed that the upcoming redevelopment of the district required a broad, citywide discussion.

In this context an initiative called Lab North was launched. Grown out of an academic master class of the University of Hasselt by architecture agency 51N4E in February 2017, Lab North is a partnership

Fig. 1 Comparison of role of meanwhile use as an act of resistance (beneath) and without impact (above) in redevelopment projects
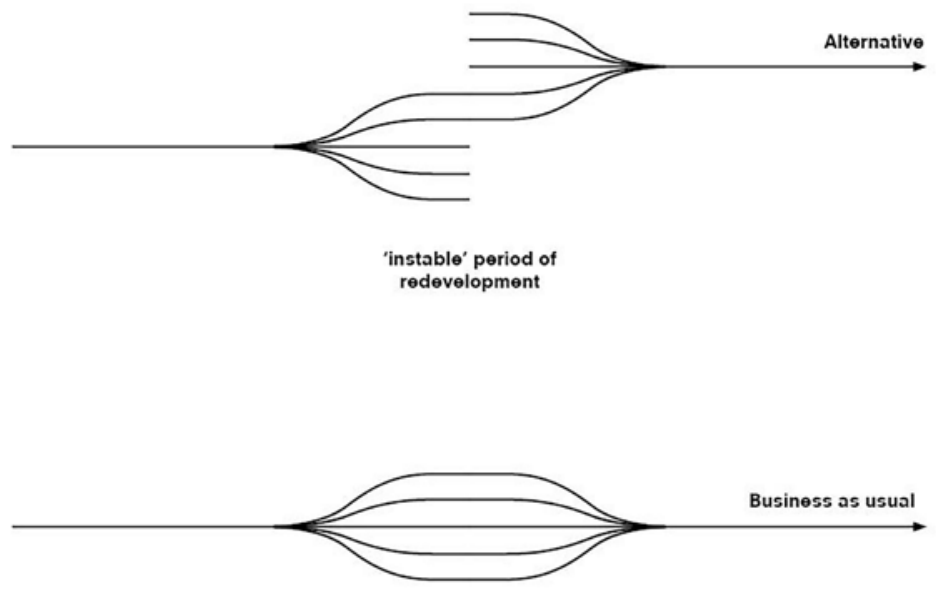

'instable' period of redevelopment 
between 51N4E, urban think tank Architecture Workroom, design agency VraimentVraiment and a non-profit, Up4North, initiated by ten property owners in the district. Lab North's mission is to 're-imagine how the district can gain back an inclusive place in the city' (Lab North 2017). One of its first operations was an open call for meanwhile use of the vacant WTCI tower for a period of one year. The purpose of this call was to 'attract a variety of actors, small or big, that can contribute to activate the area,' (Lab North 2017). A more fundamental shift that Lab North wishes to initiate is the shift from large single tenants, often multinationals or governmental agencies, to multiple smaller users sharing space and resources. 70 candidates from out of various sectors responded the call, of which most will be moving in in January 2018. I will guide you alongside three practices that moved in from September until December 2017. By describing these 'pioneering' practices, I hope to expose the conditions under which the meanwhile has come into being and in what way they are acts of resistance.

We start the tour through the building with one of the practices that co-initiated meanwhile use, $51 \mathrm{~N} 4 \mathrm{E}$, that decided to temporarily move to the WTC in September 2017.
Fig. 2 The world trade center In the 1970's surrounded by a wasteland (Copyright Collection AAM/CIVA Brussels)

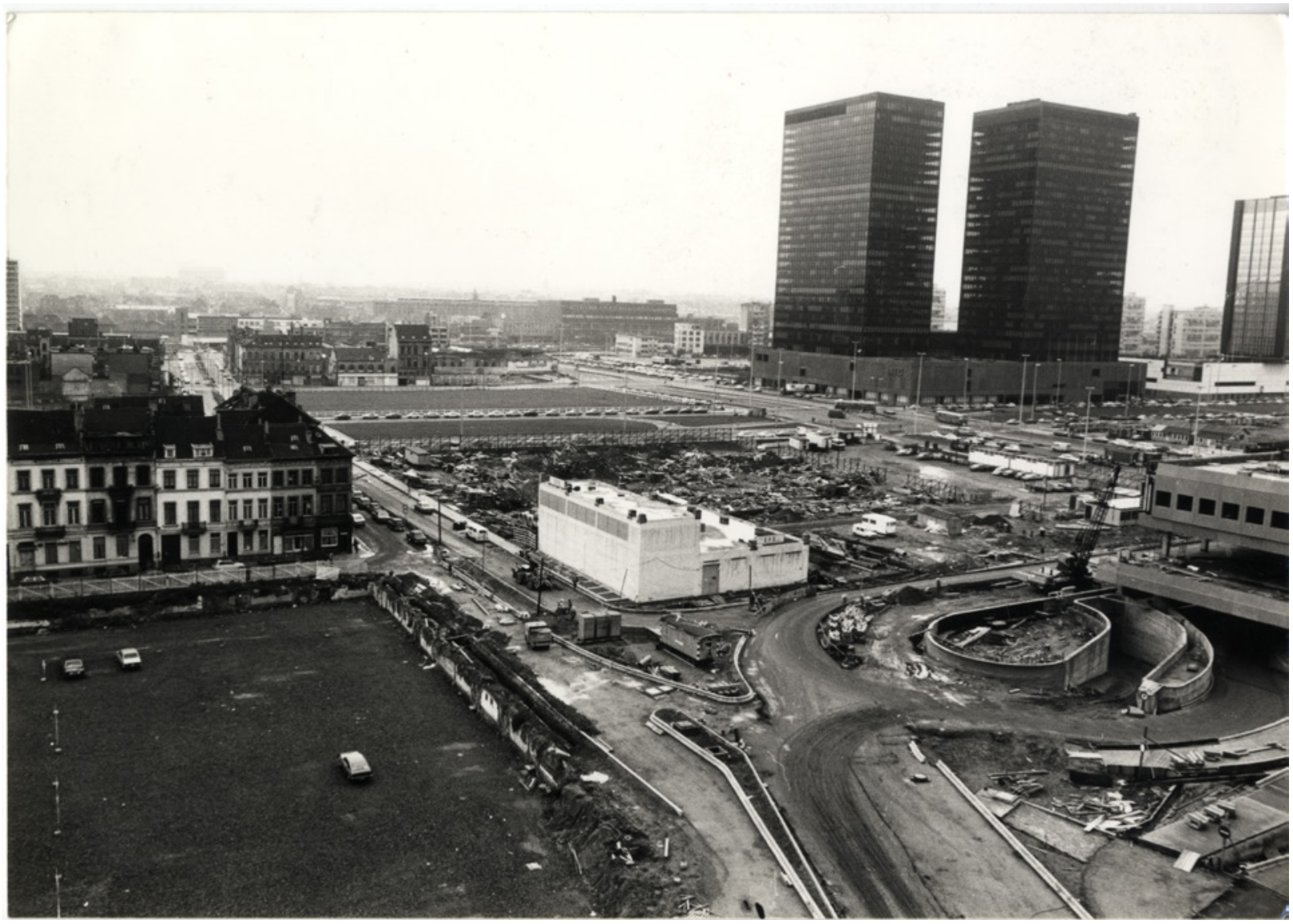


Fig. 3 Sketch by Freek Persyn of 51N4E of meanwhile use of WTCl tower (Archive of 51N4E)

Fig. 4 Student Studio of Faculty of Architecture and Arts, UHasselt on $19^{\text {th }}$ floor of WTC1 (Copyright Filip Dujardin)
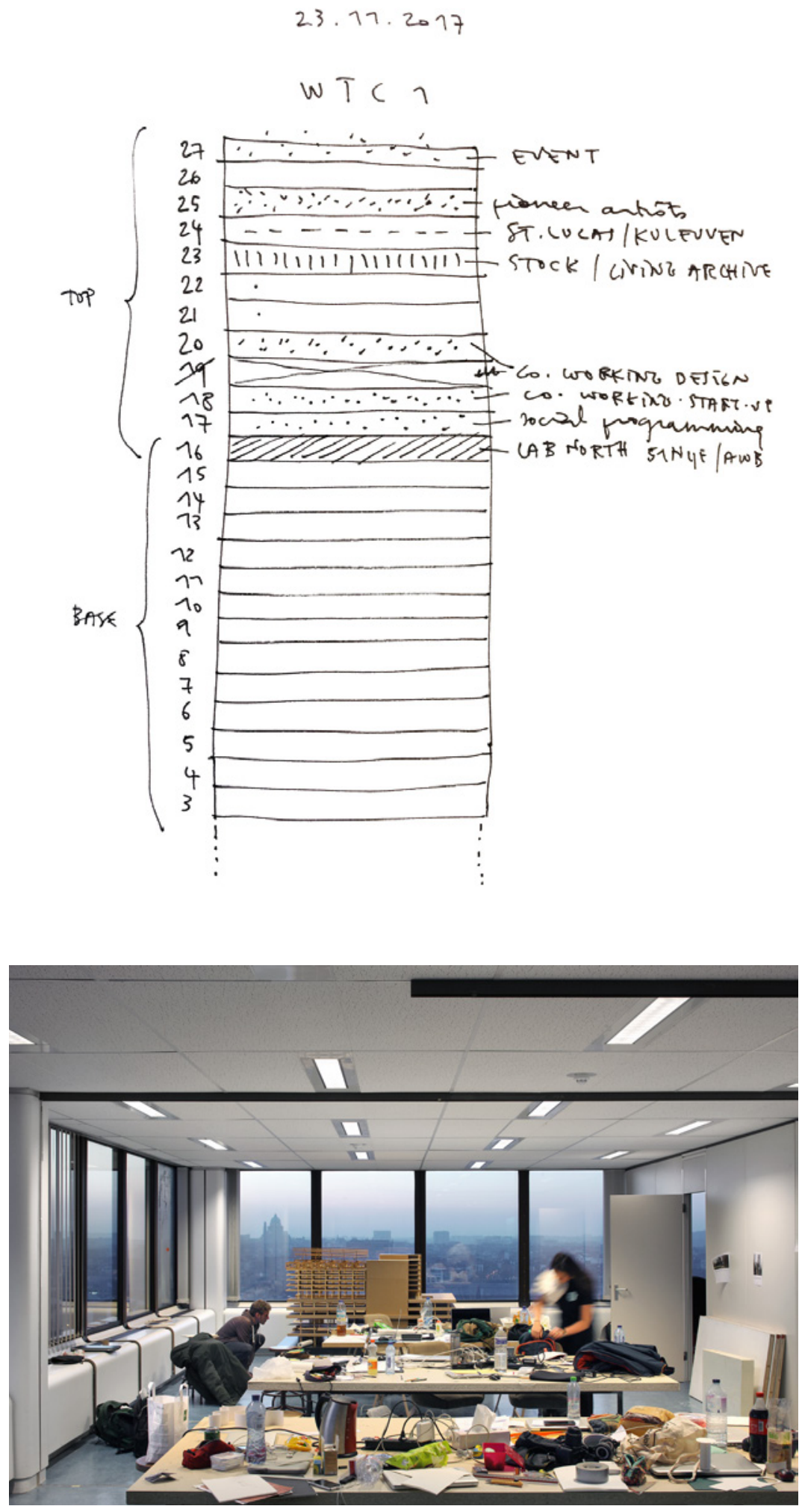
According to Freek Persyn, founding partner, the move has to do with the fact that 'there was absolutely no vision for the area' (Interview 2017). In return for architectural expertise to co-construct this vision, the engaged property owner forgoes rent and communal cost for using a 1500 square meter space, formerly used by an international construction firm. 51N4E's practice entails the making of architectural and urban projects, meetings with developers, consultants, artists and others, teaching, and various everyday activities such as of shared lunches, chitchat at the coffee machine, internal presentations, late night working sessions etc. Persyn states: 'we are starting to use it (the north district) as a city again' (Interview 2017). In December 2017, 51N4E was granted with the commission for the design of the future redevelopment of the WTC into a new 140.000 m mixed programme. Master Architect Kristiaan Borret, head in the jury for this commission, comments, 'Because $51 \mathrm{~N} 4 \mathrm{E}$ was working on the topic, it was a good candidate for this project. The added value is plural. There is knowledge production, knowledge exchange which raises the bar for all' (Interview 2017). The commission of such a project allows for a more structural influence on the actual architectural production in the district 'from within'. The brief for the commission prescribed to demolish and rebuild. With their competition design, the architects convinced the investor's team to rethink this decision and to keep and reuse parts of the building.

Let's move up, to the $23^{\text {th }}$ floor, where the Brussels campus of the University of Leuven organises their design studio in what they call the 'WTC hub'. More than a hundred architecture students carry out architectural and urban proposals, often related to the district. Two different ideas prevail when analysing this meanwhile use as educational space.

Firstly, the students' agency in the process is questioned. Peter Swinnen, professor at University of Leuven, states, 'it is absolutely not evident that students are here' (Interview 2017). It would not be the first time that students are used to increase the 'coolness' of the area and are subsequently being pushed out. The students get to discuss their role in the process of meanwhile use in a course on 'criticism and ethics.' Van de Vloet states, 'in that course we are very conscious about our role here. It's out of these courses that the notion of 'lure-hipsters' derived. If I wouldn't have had that course, I would probably have had another stance regarding this situation' (Interview 2017).

The discussion on the 'gentrifying' role of the meanwhile use influences the students' studio work. Student Elena Verelst explains how their studio aims to develop 'an approach of "integrative gentrification", in which they investigate how new socio-economic dynamics between different actors can be established' (Interview 2017). Together with her group, Elena developed an ephemeral structure of sticks and flags on the central roundabout of the district in which they welcomed a diverse crowd of people with snacks and drinks. Many showed up, ranging from refugees waiting at the immigration office to 
civil servants to local youth. One can rightfully doubt the impact this intervention will have on the relation between those groups in the long run. On the other hand, providing settings for new everyday activities does "encourage "a habitude of use" which means something might stick', affecting the process of meanwhile use (Tonkiss 2013, pp. 320).

Secondly, several students mention the contrasts between their working space on the $23^{\text {th }}$ floor and the reality on the ground floor. Anton Parys, architecture student, explains that, by working in a tower, he 'realised that things can seemingly 'work' from this height, but do not when examined downstairs. It increases your feeling of responsibility' (Interview 2017). He later states 'I never had had access to a 'private' space on such great height for such a long period of time. Being able to appropriate the space, affected me' (Interview 2017).

We finish our tour on the $24^{\text {th }}$ floor. On haphazard weekdays, handwritten flyers in the elevators notify a 'Cantine' on this floor, from noon till 2:00 pm. All ingredients are local and prepared in-situ by Joris in his improvised kitchen in a former office room. He sells meals to students, professors, artists and professionals. His practice is fragile, but his agency might be large, stimulating encounters between different actors part of the meanwhile use. Similar projects in European and Northern American cities also show how food is often embedded within other agendas (Clausen 2012, pp. 11, cited in Tonkiss 2012, pp. 316). Joris says he understands his practice as a test: "Here we learn how we will work in the future. We organise ourselves. We stimulate each other' (Interview with Joris, 2017).

\section{Conditions for resistance}

Any conclusions on the impact of the meanwhile use in the Brussels North District on the long term are impossible to draw. However, we can analyse the agency of the above-described practices. Using ActorNetwork theory, I argued that meanwhile use can be an act of resistance since it can influence choices made during the 'unstable' period of redevelopment. Five conditions can be distinguished that increase probability for this type of influencing. They represent the 'seed beds' for a meanwhile use that affects the future of the site (Tonkiss 2013, pp. 316).

\section{Use as a design process}

Meanwhile use entails testing out uses, different from those a building was designed for, as well as building new relations between the users and other stakeholders. For this testing to have impact on the result a design approach is required. A process in which design is central ensures that intentions and dreams for the future site can be expressed, negotiated and resisted, without being boxed by fixed expectations (Gieryn 2002). It also implies flexibility amongst the users: meanwhile use is unstable and changes rapidly. Such approach can be recognised in the voluntary haphazardness of Joris' lunches, as well as in the 


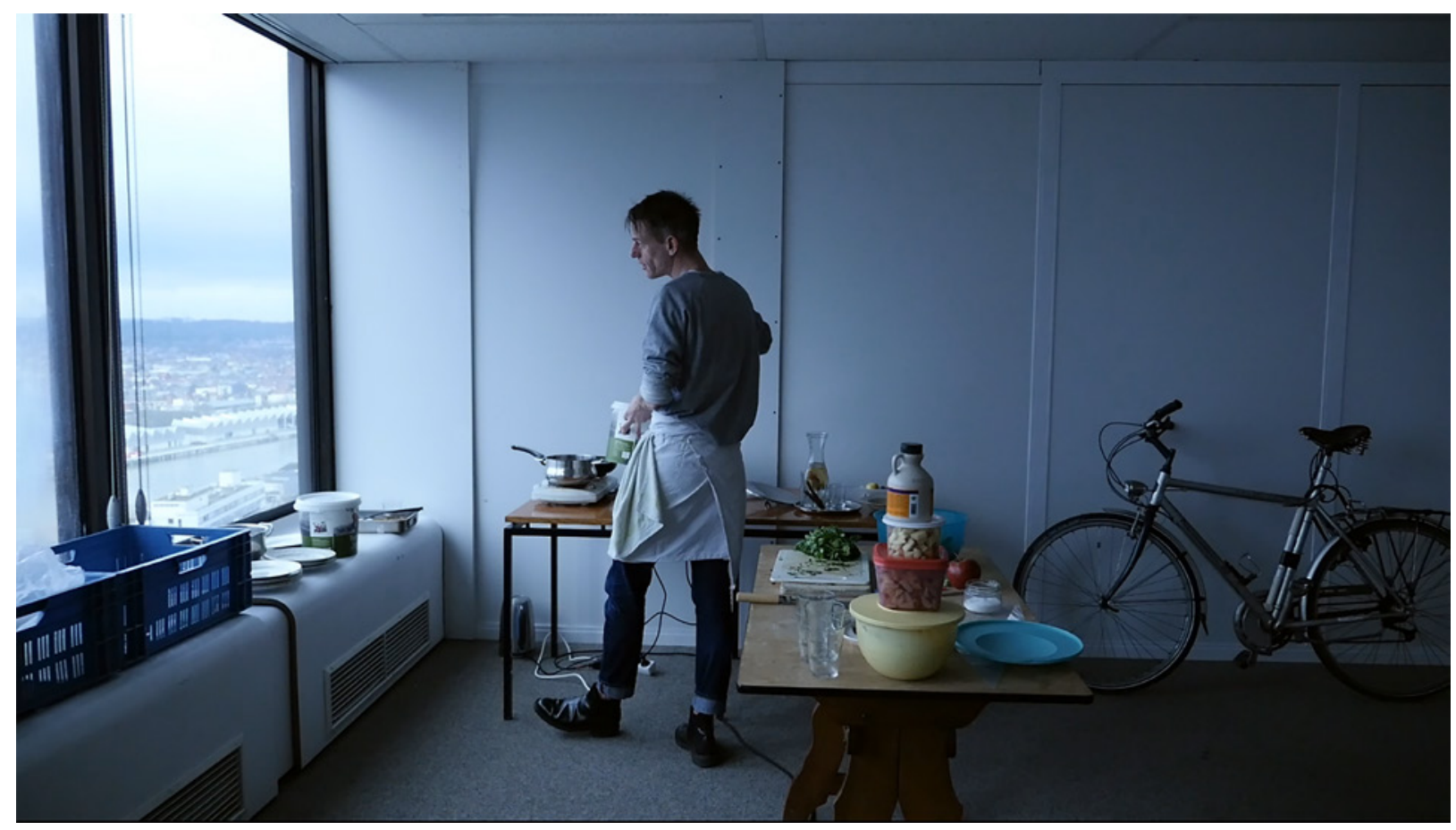

ephemeral structures set up in public space by the students. Both show, in a 'learning-by-doing' approach, how things could be organised different without proposing a final solution.

\section{A symbiotic relationship between agents}

Those involved in the meanwhile use and those deciding over the development should establish interdependency. In the architecture studio, this interdependency is most clear. Architects using the building today 'in the meanwhile' are at the same time producing the design of the future development. This creates dependencies between the 'now' and the future, between the informal and the formal. Partnerships like Lab North can enable and sustain such relation. As intermediary agent, Lab North translates and 'rewires' stakes from one milieu to the other. In that way, everyday concerns of users can reach the ear of developing parties and policy makers. These new interdependencies might give rise to a 'symbiotic relationship' between the formal and informal as called for by Mehrotra (2011), or an 'informalization' of formal institutions as presented by Boudreau (2017).

\section{Urban Futures of juxtaposed realities}

Today's tensions between meanwhile and permanent use, between formal and informal, also need to be represented in the future redevelopment plans. For this, inconsistencies should be allowed; paradoxes should be part of, even stimulated in, the imagined future
Fig. 5 'Cantine' on the $25^{\text {th }}$ floor of WTCl tower (Copyright Karine Dana) 
(Holston 2008). Today however, many redevelopment projects tend to imagine utopian futures in which all inconsistencies are being erased. This is also the case for some projects in the North District proposed by developers. The studio by the architecture students involved in meanwhile use hint towards another approach. The visions produced for the long terms should themselves contain 'cracks' for future resistance. As rightly put by architecture student Parys, the existing contradictions in the district, call for 'a more responsible' design approach (Interview 2017). This condition can be summarised as imagining a radically urban future: a collection of juxtaposed everyday realities of different identities.

\section{Critical mass}

Meanwhile use can expand its agency when it reaches a critical mass of simultaneous practices. In our case, several practices are stacked in one building, resulting in an outreach to different networks of actors and stakes in the city. This condition recalls Howard Zinn's defence for the 'countless small actions of unknown people' that could provoke structural change. An idea Noam Chomsky (2011) repeated in the wake of the Occupy Wall Street Movement. A multitude of simultaneous experiments on new forms production and consumption, on learning and working, might spawn other experiments increases the chances to impact the future development.

\section{Slowing down}

Redevelopment projects are often bound to strict planning, phasing and investment schemes that eliminate the time necessary for any of the previous conditions to develop. The conditio sine qua non would thus be to 'slow down' (Stengers 2015). This condition calls in no way for indulging the status quo, but rather to take time to reach out, change mind-sets, evaluate results and measure impacts. In the case of the North District, this time was created by an adverse office real estate market; supply exceeds demand, resulting in a slow pace of redevelopment of existing offices. Redevelopment into housing, a safer sector, would require re-zoning the area. Development has thus been slowed down. Persyn states, 'we are not working in the margin, we're almost working in an empty field. Maybe that gives a lot of back-up to succeed' (Interview 2017).

\section{Points of discussion}

In response to rightful concerns about risks of meanwhile use as a catalyst for gentrification and displacement - meanwhile use might affect the outcome, but for whose benefit? - I posit two points of discussion.

The first concern deals with the policy framework for meanwhile use. Urban redevelopment is largely driven by mechanisms of spatial transformation, ranging from master plans till territorial visions. In many cases, the planning of use remains under-developed. In Brussels, 
the government is piloting in a couple of projects with meanwhile use to anticipate on and test new programs and services. But as much as use should be stimulated, sometimes 'it should also be contained at a certain point' (Borret in Interview 2017). What kind of policy and planning approach can be developed that stimulate meanwhile use but also prevents pushing out other, sometimes vital part of our cities?

The second point of discussion considers the position of the activist urbanist. In many cases of meanwhile use, urban practitioners are involved. Architects, urban designers, urbanists that combine a professional with an activist role. This results in a shift in the discipline to self-organised, low - or unpaid work. Our case's example shows how a new economy of means can mediate this shift, by trading, for instance, expertise for space. What other mechanisms of such an economy of means can be developed? They will prove crucial in sustaining the 'countless small practices' who run meanwhile use and provide ideas, intelligence and energy (Chomsky, 2011).

\section{Conclusion}

Urban transformation has become a ubiquity in European and North American cities. Enclosed spaces, long-term vacancy, lock-down, and deconstruction are part of this process. In this essay, I argued that in this context, practices can unfold 'from within' that affect the future of those urban sites. Practices of meanwhile use that learn from modest, everyday experiences to imagine alternative urban futures. In order to have impact on the further course of the transformation, I advocated five conditions to be nurtured. The case revealed more in detail what shapes resistance can take. Parallel to their every-day activities, the users described push for other agendas, dealing with questions of health, more sustainable building methods and new forms of education.

This article is a reworked version of the paper written at the Cities Programme, LSE under supervision of Dr. Suzanne Hall and Julia King. The research was cunducted as part of their course 'Cities by Design' in 2017. 
Binst, Jean-Marie (2016). Nog meer leegstand verwacht in de noordwijk. (Online) Available at: http://www.bruzz.be/nl/actua/nog-meer-leegstandverwacht-noordwijk. (Accessed 13 November 2017)

Bogdan\&VanBroeck and Idea Consult (2013). Ferraris. Unpublished study for the Flemish government.

Boudreau, Julie-Anne (2017). Global Urban Politics. Informalization of the State. Cambridge: Polity Press -

Chomsky, Noam (2011). Occupy. London: Penguin

Clausen, Marco (2012). 'Prinzessinnengärten', Make-Shift: The Expanded Field of Critical Spatial Practice, pp. 11-12. Berlin: TU Berlin, Institute for Architecture.

Doucet, Isabelle (2015). The practice Turn in Architecture: Brussels after 1968. New York: Ashgate.

Gieryn, Thomas F. (2002). 'What buildings do', Theory and Society, Volume 31, No. 1, pp. 35-74.

-

Guggenheim, Michael (2014). 'From Prototyping to Allotyping', Journal of Cultural Economy, 7(4), pp. 411-433.

-

Holloway, John (2010). Crack Capitalism. London: Pluto Press.

Holston, James (2008). 'Spaces of Insurgent Citizenship', Making the invisible visible. A Multicultural Planning History, Berkeley and Los Angeles: University of California Press.
Lab North (2017) More about the lab. (Online) Available at: www.labnorth.be. (Accessed 13 November 2017)

Latour, Bruno and Yaneva, Albena (2009). 'Give me a gun and I will make all buildings move, an ANT's view of architecture', Explorations in Architecture: Teaching, Design, Research, ed. Geiser. Reto. Basel, Boston, Berlin: Birkhauser, pp. 80-89.

Lefebvre, Henri (1991). The Production of Space. trans. D. Nicholson-Smith. Oxford: Basil Blackwell -

Martens, A. (2009). De hedendaagse erfenis van tien jaar onteigeningen en uitzettingen in de Brusselse Noordwijk (1965-1975). (Online) Available at: http://brussels.revues.org/690. (Accessed 13 November 2017)

Mayer, Magret (2013). 'First World Urban Activism: Beyond Austerity Urbanism and Creative City Politics', City, 17(1), pp. 5-19.

-

Mehrotra, Rahul (2007) 'Kinetic City, Issues for Urban Design in South Asia', article based on Mehrotra, Rahul (2007). 'Negotiating the Static and Kinetic Cities', Urban Imaginaries, ed. Huyssen, Andreas. Durham, NC: Duke University Press.

Metaal, Stefan (2007). 'Gentrification, an Overview', Journal for Architecture OASE, 73, pp. 8-28.

Mitchell, Don (1995). 'The end of public space',

Annals of the Association of American Geographers, Vol. 85, No. 1, pp. 108-133.
Osman, Suleiman (2011). The invention of Brownstone Brooklyn: Gentrification and the search in Postwar New York. Oxford: Oxford University Press.

-

Smith, Neil (1996). The New Urban Frontier, Gentrification and the Revanchist City. London and New York: Routledge.

Stengers, Isabelle (2015). 'The Cosmopolitan Proposal', Making Things Public - Atmospheres of Democracy, ed. Latour, Bruno et al. Cambridge MA: ZKM and MIT Press, pp. 994-1003.

Stuart Hodkinson (2012). 'The New Urban Enclosures.' City, 16(5), pp. 500-518.

Tonkiss, Fran (2013). 'Austerity urbanism and the makeshift city', City, 17(3), pp. 312-324.

-

Vasudevan Alexander (2017). The Autonomous City. A History if Urban Squatting. London and New York: Verso.

-

Zukin, Sharon (2010). The Naked City: The Life and Death of Authentic Urban Places. Oxford, USA: Oxford University Press. 